\title{
Dengue control in Ribeirão Preto, São Paulo, Brazil
}

\author{
A experiência do controle do dengue \\ em Ribeirão Preto, São Paulo, Brasil
}

\author{
Afonso Dinis Costa Passos 1 \\ Eugênia Maria Silveira Rodrigues 2 \\ Amaury Lelis Dal-Fabbro ${ }^{1}$
}

\footnotetext{
${ }^{1}$ Departamento de Medicina Social, Faculdade de Medicina de Ribeirão Preto, Universidade de São Paulo. Av. Bandeirantes 3900 , Ribeirão Preto, SP 14049-900, Brasil. 2 Divisão de Controle de Vetores, Secretaria Municipal de Saúde de Ribeirão Preto. Rua Flávio Uchoa 1180 , Ribeirão Preto, $S P$ 14085-600, Brasil.
}

\begin{abstract}
Following an epidemic of type I dengue in late 1990, the municipality of Ribeirão Preto (State of São Paulo, Brazil) assumed direct responsibility for the control of Aedes aegypti larvae. Control activities are presented in this report and are based on popular participation and environmental management. Massive use of the communications media, participation by schoolchildren, constant contact with the population, and integration of various public agencies are the program's priorities. Although the drop in the number of susceptibles may have played a role in the reduction of cases after the initial epidemic, the intense preventive campaign certainly helped quell the disease in the city, since changes were observed in the behavior of the population towards potential breeding sites. The occurrence of new cases in recent years appears to be related to greater circulation of the virus in both the State of São Paulo and Brazil as a whole, indicating the need for control measures at the national and continental level, without which it will be difficult to maintain low transmission rates, even in areas submitted to intense preventive work.
\end{abstract}

Key words Dengue; Communicable Disease Control; Community Participation; Consumer Participation

Resumo Após uma epidemia de dengue tipo I no final de 1990, a cidade de Ribeirão Preto (Estado de São Paulo, Brasil) assumiu as atividades de combate às larvas do Aedes aegypti. Tais atividades, baseadas em participação popular e manejo ambiental, são sintetizadas neste trabalho. Utilização maciça dos meios de comunicação, participação de escolares, contato constante com a população e integração de diferentes órgãos públicos são atividades priorizadas pelo programa. Embora a redução de susceptíveis possa ter contribuído para o decréscimo de casos nos anos após a epidemia, o intenso trabalho profilático deve ter exercido papel relevante no controle do dengue na cidade, uma vez que mudanças têm sido observadas em relação ao cuidado com criadouros potenciais. O ressurgimento de casos em anos recentes parece ser devido à maior circulação do vírus no Estado e no País. Tal fato aponta para a necessidade de medidas de controle em nível nacional e continental, sem o que torna-se difícil a manutenção de níveis reduzidos de transmissão, mesmo em áreas intensamente trabalhadas.

Palavras-chave Dengue; Controle de Doenças Transmissíveis; Participação Comunitária 


\section{Introduction}

Dengue is an acute infectious disease caused by a virus of the family Flaviviridae, genus Flavivirus, with four serotypes (1, 2, 3 and 4). The virus is transmitted by Aedes aegypti and Aedes albopictus mosquitoes, with man being the only known vertebrate host. The disease covers a broad spectrum of clinical manifestations: asymptomatic forms, oligosymptomatic forms, dengue fever (or classic dengue), hemorrhagic dengue, and dengue shock syndrome. The hemorrhagic forms and dengue shock syndrome are associated with more serious and occasionally fatal outcomes (WHO, 1987).

Dengue is widely distributed all over the world, occurring in various continents and regions including Southeast Asia, Central America, the Caribbean Islands, South America, and Africa. In Southeast Asia, dengue is an important cause of infant mortality because of the incidence of hemorrhagic forms (WHO, 1987). In Brazil, in recent years, the first cases of dengue occurred in Boa Vista, Roraima, in 1980-81 (Osanai et al., 1983). In 1986, an epidemic occurred in Rio de Janeiro, with more than one million cases (Figueiredo et al, 1990), and the disease began to appear thereafter in several other States. In 1987, the first cases occurred in the State of São Paulo (Tengan \& Katz, 1996).

A dengue epidemic caused by serotype 1 occurred in 1990-91 in Ribeirão Preto (Pontes, 1992), a city located in the northeastern region of the State of São Paulo, with a population of about 432,000 inhabitants (1996). Approximately 8,900 cases of classic dengue were reported, with an incidence coefficient of more than 550 cases per 100 thousand inhabitants in 1990 . Following the epidemic there was a period of limited transmission, with few confirmed cases from 1992 to 1994. In 1995 there was a recrudescence of transmission that continued through 1996 and 1997, although at lower levels than observed during the epidemic.

Until the late 1980s, control of dengue vectors in the State of São Paulo was the exclusive responsibility of the Superintendency for the Control of Endemic Disease (Sucen). Since 1989-90, these activities have been shared by Sucen and the Municipal Health Department in Ribeirão Preto. Measurement of larval infestation indices and vector control during situations of transmission thus continued to be performed by the State agency, whereas control of larval forms of vector mosquitoes came under the municipality's responsibility.

The purpose of this article is to present and discuss the more relevant experience in terms of dengue control thus far in Ribeirão Preto, with emphasis on the activities for which the Municipal Health Department is responsible, i.e., the systematic control measures aimed at larval forms of the vectors.

\section{Current activities}

Soon after the municipalization process outlined above, in 1989-90, the activities delegated to the municipality consisted of the traditional door-to-door or household visits for the detection and destruction of larval foci of Aedes aegypti and Aedes albopictus and application of larvicides. Experience in this field work led to the establishment of two priorities for positive results in the fight against the vector, i.e., effective community participation in the implementation of control measures and environmental management activities, especially removal and proper disposal of solid waste and cleaning of urban lots.

The experience reported below is based on this joint activity, emphasizing implementation and results.

\section{Participation by schoolchildren}

Through the School Health Care Program of the Municipal Health Department, students from the public school system were encouraged to participate in activities involving discussion of dengue vector control, including the following:

A poster contest, in which the prize-winning poster became an outdoor ad displayed in highly visible places around the city, essay contests, scavenger hunts amongst the various schools for collecting (and thereby eliminating) breeding sites for Aedes aegypti, science fairs, staging of plays, parades, and lectures.

Educational gifts to be awarded as prizes were prepared, with information about the vectors. A book about Aedes aegypti was produced and distributed to all public libraries for use as teaching material. Adults were often attracted to the school activities, especially the lectures, science fairs, plays, and parades. Neighborhood associations and local health committees helped the schools organize these events, with the support of the Vector Control Division.

\section{Use of the mass media}

The mass communications media were used extensively in the dengue control activities. To illustrate, in 1997 alone some 25 interviews were aired on local TV stations, in addition to 
20 on local radio stations; some 25 interviews appeared in the newspapers. The most popular local TV channel chose dengue control activities as one of its main priorities in reports on health. This channel reaches 62 towns in the Ribeirão Preto area, with a population of approximately two million people. The station has kept up close contact with the Vector Control Division and is always available for broadcasting news on the dengue problem or interviewing people involved in the campaign against Aedes aegypti.

One of the most interesting experiences was a content held on radio programs with the largest audience. The listener would call the station and request a visit by technicians from the Vector Control Division. The visit was made, and if the household was found to be free of breeding sites for Aedes aegypti, the person requesting the visit won a box of groceries supplied by the sponsors. The contest was preceded by information about Aedes aegypti and the risks of the disease caused by this vector.

\section{Vector reporting by the population}

Using the 156 system, a free telephone hotline set up to receive complaints from the local population, the people report the presence of mosquitoes in or around their homes. The information is passed to the Vector Control Division, which provides the service requested. People working in this system are trained on the biology of Aedes aegypti and Culex and are familiar with vector control work routines. The hotline is used to schedule home visits and removal of used tires at tire shops and other solid waste that can include potential breeding sites for Aedes aegypti.

\section{Communication with the population by letter and cards}

A constant communications channel with the population has been maintained through correspondence sent by the Vector Control Division to stores and private homes. Letters are sent periodically to commercial establishments considered to be prime spots for the proliferation of Aedes aegypti, such as tire shops, tinsmith shops, flower shops and building sites. The content of these letters mentions the potential risks in these sites and recommends constant surveillance. After the letters are sent, the establishments are visited to training the owners, managers, and employees.

Educational leaflets were printed in green, yellow and red. The colors are the same as those of traffic lights in order to take advantage of known parameters. The colors of the leaflets left at households and commercial establishments vary according to the situation found. A green leaflet is left when no irregular situation favoring proliferation of Aedes aegypti is detected, with a message of congratulations for the care taken by the resident. The yellow leaflet warns about the need to correct irregularities and the fact that punitive measures may be taken if recommendations are not complied with after an specified period of time. The red leaflet is left when the building is in imminent danger of dengue transmission, and a copy of the visit record is forwarded to the Health Surveillance Division, which then subpoenas the person.

\section{Production and use of educational materials}

Different types of educational materials have been used to educate and stimulate participation by the population. The materials target specific publics. A video, an illustrated leaflet, and a portable set of posters were prepared for use by community leaders, covering the history of dengue, clinical signs and symptoms, the Aedes aegypti life cycle, the most frequent breeding sites, control measures, and logistics for participation by the population at large. A folder focusing specifically on hemorrhagic dengue was distributed to the primary health care clinics in the area, referring them to epidemiological surveillance professionals for further details on the disease. Posters on dengue, Aedes aegypti, and hemorrhagic dengue have been exhibited at health centers and hospitals.

Another video was developed specifically for health professionals, with a more technical content and general information on the virus, the disease, and diagnostic methods. This material is used to train health teams (especially physicians and nurses) at the health centers to provide the necessary information for early diagnosis of dengue in its different clinical forms and to motivate them to recognize the relevance of case reporting.

\section{Motivation and work by the population during routine home visits}

Municipalization (i.e., decentralization to the municipal or county level) of the Aedes aegypti control measures through the Vector Control Division in Ribeirão Preto is based on establishing good ties with the local population. Employees are trained to understand that the main goal of the work should always be to im- 
prove the population's quality of life through vector control activities. Each resident thus becomes a protagonist in the search for alternatives and solutions for Aedes aegypti and Culex sp. control in unison with public health authorities, with a view towards controlling diseases like dengue and yellow fever.

Employees learn all about the institution in order to pass on information about municipal services during home visits, informing residents about their rights and not simply reminding them of their duties. This is because each employee is considered an agent for changing the population's living conditions.

One of the main objectives of home visits is thus the identification and elimination of Aedes aegypti foci, coupled with information and education. An average of 15,000 home visits are made per month, about $12.5 \%$ of the buildings in the city. Each building is visited at least once a year and some more than once, producing broad coverage of the educational activities. Most residents are able to talk personally to vector control workers once a year or more.

\section{Joint activities by public agencies}

The decision was made at the beginning of dengue control activities in Ribeirão Preto to coordinate activities by the various government agencies involved in urban cleaning and sanitation, with a view towards an environmental management approach allowing for the destruction of mosquito breeding sites. Meanwhile, the Health Inspection and Epidemiological Surveillance Divisions were merged to maximize the results of the various measures.

Top priority is the clearing of empty lots where people dump garbage, where huge amounts of empty containers accumulate that can act as mosquito breeding sites. Neighborhoods with substandard sanitation are selected and community leaders are contacted and asked to participate in meetings to establish priorities for public agencies. On scheduled dates, these agencies provide a range of services in a concentrated effort to solve the neighborhoods' problems, including cleaning of lots and small streams and activities aimed at solving larger problems such as water supply, paving, and cleaning of manholes and culverts. Intensive backyard clean-up drives are carried out simultaneously to eliminate Aedes aegypti foci. Vector control thus becomes one of the population's own priorities, thereby gaining credibility. This type of work has been defined in various ways and is often called "community operations".
During the more critical periods of the year for Aedes aegypti infestation, the summer rainy season, intensive clean-up drives are carried out in a series of neighborhoods selected among those with the highest larval indices. Since 1991, such intensive clean-up projects have been carried out at least once a year in a total area of approximately one-fifth of the entire county of Ribeirão Preto (20-25 thousand buildings). Several public agencies collaborate on these projects for four or five days a week to reduce the number of containers in backyards and empty lots, thus reducing the vector foci. Military police and military recruits have helped implement these intensive operations.

Some commercial, industrial, and service establishments accumulate large amounts of containers with water, fostering presence of Aedes aegypti larvae. These include tire shops, repair shops, construction sites, flower shops, lumber yards, and even some government agencies. Because of their size, these establishments may produce large numbers of mosquitoes which go on to infest other nearby buildings. Priority is thus given to control activities in these locations, labeled "strategic points" under the Aedes aegypti control program. An educational program was started with the managers of these establishments, based on visits, instructions, and distribution of leaflets. In tire shops, old tires are systematically collected and trucked to the city dump. Where such establishments resist the instructions, educational activities are supplemented by punitive measures provided for under the municipal health code.

Equally important has been the joint action with the Division of Epidemiological Surveillance, fostering more rapid application of collective protective measures in the presence of suspected cases. Reporting by the health units is transferred by phone to the Vector Control Division, which visits households, workplaces, and schools with suspected cases. During visits, Aedes aegypti foci and the presence of persons with dengue-like symptoms are investigated. When a case is confirmed by laboratory tests, Sucen starts a "focus blockade" by spraying the households in the immediate vicinity.

\section{Results and discussion}

After the major epidemic from late 1990 to early 1991, dengue incidence in Ribeirão Preto showed a marked decline over the following three years, from 546.9 cases per 100,000 inhabitants in 1990 to 56.7 in 1991, 1.6 in 1992, 
and 0.9 in 1993 and 1994 (Figure 1). A subsequent rise occurred in 1995 and 1996, with 45.8 and 56.0 cases per 100,000 inhabitants, respectively.

Even considering a drop in the number of susceptibles after the late-1990 epidemic, and a resulting reduction in conditions tending to maintain high transmission levels, it is highly probable that the control activities implemented in Ribeirão Preto after the epidemic contributed to the drastic reduction of incidence coefficients. Indeed, some actions resulted in the dissemination of information on the disease and its transmission mechanisms. The intensive use of mass communications media, especially radio and television, facilitated the work of the teams in charge of door-to-door visits, which began to be more readily accepted, fostering closer interaction with the population. Obviously, knowing about the disease and its transmission does not automatically imply a change in attitude, as shown by the countless difficulties in obtaining compliance by broad segments of the population involving the adoption of simple waste disposal measures to interrupt the vector's life cycle. Interestingly, the greatest resistance to such measures came from the two population extremes. On the one hand, people living in peripheral areas, particularly poverty-ridden, environmentally polluted slums, with the predominance of breeding sites deriving primarily from the destitute conditions of the inhabitants themselves. On the other, paradoxically, higher-income neighborhoods, tending to be more reluctant to have their homes visited or to accept suggestions to prevent breeding sites (like potted plants and swimming pools). In 1995 and 1996 the highest larval indices in the city were detected in a middle-to-upper-middleclass neighborhood located close to the Campus of the University of São Paulo, where a number of professors live (Dal-Fabbro, 1997).

Such difficulties show the gap between receiving information and changing one's attitude, emphasizing the limitations of largescale educational campaigns. In some cases, especially in situations involving commercial establishments at high risk for the proliferation and dissemination of Aedes aegypti, whose owners were reluctant to cover the costs of the necessary changes, the most effective measure was pressure from the Health Inspection Division, with warnings and fines according to the situation and the response. This measure, although efficient for private enterprises, was ineffective for government agencies which were sometimes in a chaotic situation, with an abundance
Figure 1

Dengue incidence by year. Ribeirão Preto, Brazil.

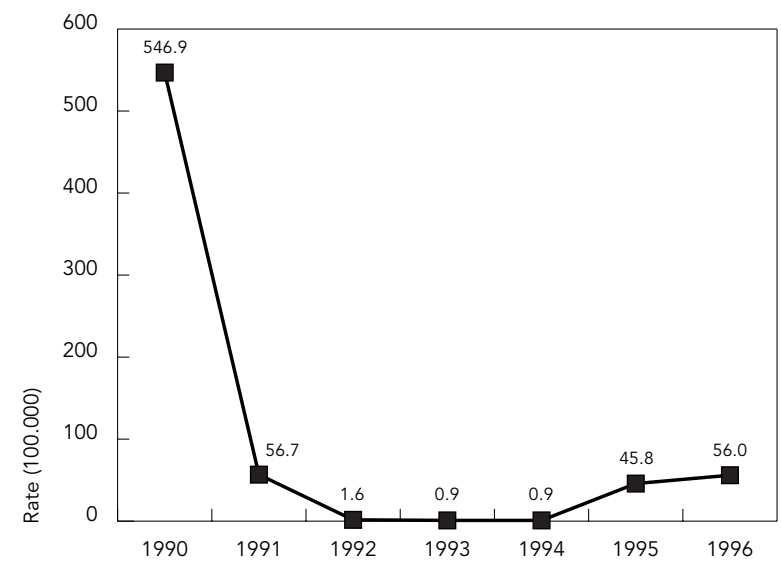

of vector breeding sites. We could cite the facilities of the State Foundation for the Welfare of Minors (Febem) in Ribeirão Preto, repeatedly identified by the Vector Control Division as being at high risk for the transmission of dengue due to the presence of large amounts of Aedes aegypti larvae, with a recent severe outbreak among the minors and employees (unpublished data).

However, even with these limiting factors and despite the lack of a systematic evaluation of the control measures, there is some clear evidence of progress. Some examples are the undeniable reduction in potential breeding sites in the backyards of a considerable proportion of the population, marked improvement in many commercial establishments such as flower shops and tire shops, reduction of breeding foci at construction sites, and the systematic use of moistened sand instead of water in cemetery flower vases. These behavior changes, although still leaving much to be desired for the community as a whole, indicate that advances can be achieved by maintaining lasting control programs using different alternatives to enlist cooperation from the population. Especially relevant are the programs actively involving schoolchildren, since the latter are usually quite receptive to educational messages. The reach and the multiplying effect of these programs can be evaluated on the basis of parents' participation in some activities involving schoolchildren, like lectures, science fairs, skits, and parades. Equally important is the involvement of the neighborhood Associations and local health committees, collaborating with the 
Figure 2

Dengue cases in Ribeirão Preto and the State of São Paulo by year.

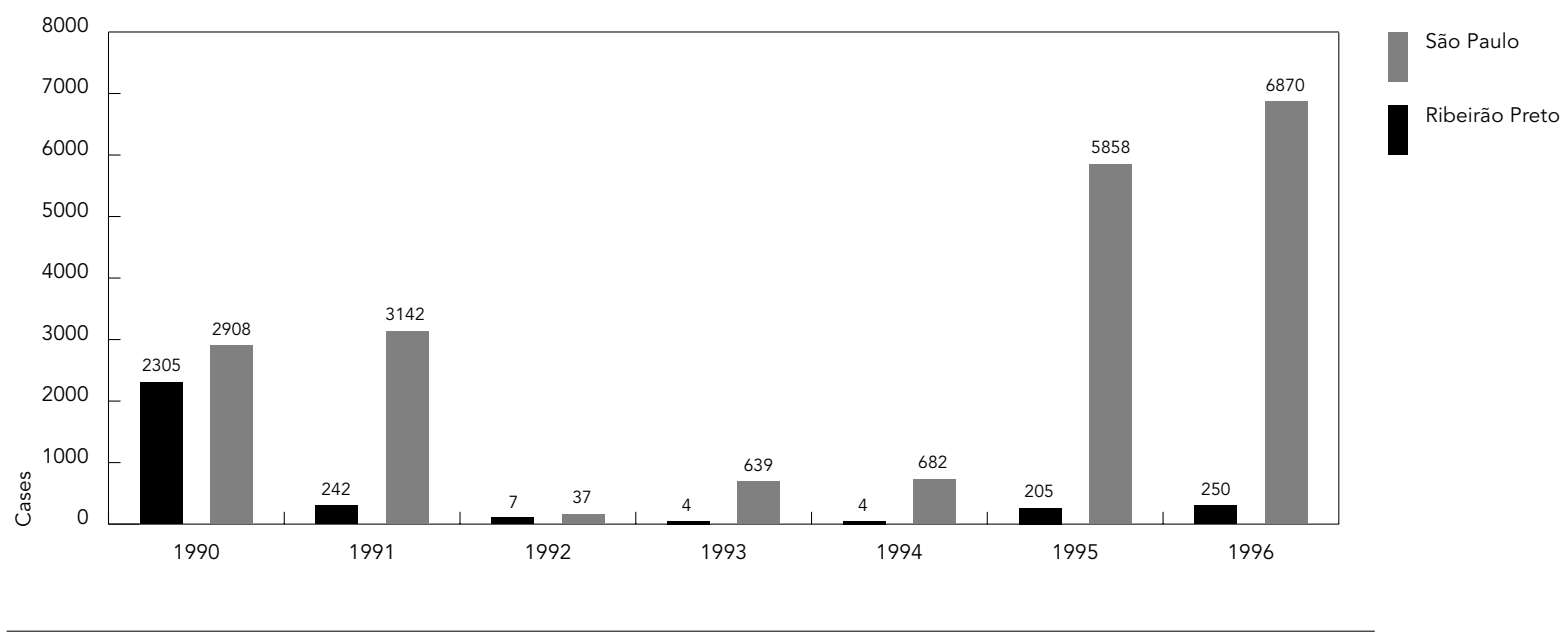

schools on several occasions in organizing these events.

A highlight of the Ribeirão Preto program is the prompt reporting of suspected cases and the prompt response. This rapid triggering of investigative and blockade measures is crucial to efficient performance in reduction of transmission in areas affected by dengue.

Obviously, much remains to be done to achieve effective dengue control in Ribeirão Preto, despite the advances described above. Proof of this is the upturn in incidence coefficients in 1995 and 1996, virtually returning to the figures from 1991 (Figure 1), despite the preventive work. A partial explanation is the dissemination of dengue in both Brazil as a whole and the State of São Paulo in recent years. Figure 2 shows that the importance of

\section{References}

DAL-FABBRO, A. L., 1997. Estudo Epidemiológico do Dengue em Ribeirão Preto no Período 1990-1997. Doctoral thesis, Ribeirão Preto: Faculdade de Medicina de Ribeirão Preto, Universidade de São Paulo

FIGUEIREDO, L. T. M.; CAVALCANTE, S. M. B.\& SIMÕES, M. S., 1990. Dengue serologic survey of school-children in Rio de Janeiro, Brazil, in 1986 and 1987. Bulletin of the Panamerican Health Organization, 24:217-225.

OSANAI, C. H.; TRAVASSOS da ROSA, A. P. A.; TANG, A. T.; AMARAL, R. S.; PASSOS, A. D. C. \& TAUIL, P. L., 1983. Surto de dengue em Boa Vista, Roraima. Nota Prévia. Revista do Instituto de Medicina Tro- cases diagnosed in Ribeirão Preto compared to the State as a whole was markedly reduced when 1990 is compared to the following years. This demonstrates a more intense viral circulation in other areas of the State in recent years, reflecting a trend observed in other Brazilian States (Tengan \& Katz, 1996). The relevance of Ribeirão Preto as a center for regional development and strategic communications with other regions in the country, many of them undergoing dengue transmission, results in increased pressure for viral entry. This fact extrapolates regional borders and suggests the need for effective dengue control at the national (or preferentially continental) level, without which it will be very difficult to maintain low levels of transmission in isolated areas or municipalities, despite intensive preventive work. pical de São Paulo, 25: 53-54.

PONTES, R. J. S., 1992. Estudo da Epidemia de Dengue no Município de Ribeirão Preto - SP, 1990-1991. Tese de Doutorado, Ribeirão Preto: Faculdade de Medicina de Ribeirão Preto, Universidade de São Paulo.

TENGAN, C. H. \& KATZ, G., 1996. Dengue: situação atual. Boletim Informativo do Centro de Vigilância Epidemiológica "Prof. Alexandre Vranjac", São Paulo, 47: 6-8.

WHO (World Health Organization), 1987. Dengue Hemorrágico: Diagnóstico, Tratamento e Controle. Genebra: WHO. 